\title{
PREREQUISITES OF AN ADEQUATE THEORY OF AGING: A CRITIQUE AND RECONCEPTUALIZATION*
}

\author{
Robert John \\ University of Kansas
}

Mid-American Review of Sociology, 1984, Vol. IX, No. 2:79-108

Over the last thirty years a number of theories have purported to give gerontological researchers a special insight into the aging experience by emphasizing several key issues around which to conduct research and interpret the status of the elderly. Each of these theories has focused on one or two key elements thought to profoundly affect the aging experience. The purpose of this essay is to analyze these theoretical developments for their specific contributions and identify the theoretical prerequisites of an adequate theory of aging. In so doing, I advance three contentions. First, a special theory of aging is unnecessary and, perhaps, undesirable. ${ }^{1}$ Second, no single theory of aging yet proposed provides an adequate account of the aging process, although existing theoretical developments have identified important elements that need to be integrated into a unified theoretical orientation. Finally, I maintain that a synthesis and elaboration of elements drawn from existing theories does provide an adequate framework for the direction and interpretation of research. Prior to my purposefully selective review of the theoretical literature in which I analyze the strengths and weaknesses of the competing theories, I will describe and assess the importance of the four elements that emerge from previous theoretical formulations as necessary components of an adequate theoretical approach to the aging process.

*This is a revision of the paper that was awarded Second Prize in the Midwest Sociological Society Caroline Rose Paper Competition, 1983. Partial support for this research was provided by a National Institute on Aging predoctoral fellowship directed by the Midwest Council for Social Research in Aging. I would like to thank Warren A. Peterson, Director, and Harold L. Orbach for their suggestions and comments. I am especially grateful for the encouragement and helpful suggestions made by Jill S. Quadagno and Timothy Diamond. 


\section{An Historical Orientation}

This element must be understood in two ways. In the first instance, social gerontologists must recognize that any theory of aging is applicable to only a limited historical period. This is nothing more than the recognition of the historicity of the theory itself. No universal theory of aging can explain the meaning of growing old for all historical eras, nor can any theory apply to all cultures and political economic formations. ${ }^{2}$ The goal of theory in social gerontology is achieved when a researcher can specify the implications of growing old given a certain set of material and ideal conditions in a particular society. ${ }^{3}$ That is to say, it is necessary to recognize such things as the effects of the age structure of the population, the level of technological and economic development, the extent of concentration of wealth and political power, the role of the state in economic and social matters, as well as people's beliefs, attitudes, opinions and values.

The second meaning of an historical orientation is more familiar. Theory in social gerontology must lead the researcher to consider the effects that historical processes and events have on the aging experience. ${ }^{4}$ The example of the election of Ronald Reagan and his subsequent attempt to alter the relationship between the state and the elderly should suffice as an illustration of an event that resulted in an attempt to put a process into motion that could dramatically change the meaning of growing old for millions of people. That Reagan had only limited success in changing this relationship during his first term provides further support for the importance of an historical perspective in explaining the existence of a given set of material and ideal conditions with which he had to contend. In this case both material and ideal conditions were impediments that Reagan and his advisors judged, from a strictly pragmatic viewpoint, to be insuperable. Important material conditions include the simple fact that the "elderly" comprise 11 percent of the population, or more to the point, routinely comprise 15 percent of the people who vote in national elections. Leaving aside whether Reagan subscribes to any of the "myths" of senior political power (Riemer and Binstock, 1980; Cf. Estes, 1978, 1979a), Reagan's policies toward the elderly quickly shifted from a frontal assault on benefits provided or guaranteed by the state, to an effort to trim benefits in less obvious ways.

Another material presence that impedes any drastic change in government programs for the elderly is what Carroll Estes (1979b) has termed the "aging enterprise." By this Estes is referring to the burgeoning service industry of national, state, and local organizations (both public and private) that have a vested interest in the continuation of funding for the elderly. A direct outgrowth of the Older Americans Act and Medicare legislation, this group of service organizations aggressively works to identify new service needs and resists attempts to dismantle programs already in operation. So-called interest group organizations, such as the American Association of Retired Persons or the National Council of Senior Citizens are a similar material impediment to drastic changes in social policy.

In addition to these material considerations, Reagan was forced to limit budget cuts in programs for the elderly because the ideal conditions did not support his political position. Public opinion polls reveal that Americans, in general, believe that the elderly cannot simply be left to fend for themselves as best they can but that the state must provide an adequate level of support. ${ }^{5}$ The results of a series of public opinion surveys on social security conducted over the last few years by a variety of polling organizations reveal widespread opposition to the changes Reagan proposed for the Social Security system. Americans' concern and sympathy for the status of the elderly can be seen in their belief that "Reagan's economic policies such as his budget and tax cuts ... will be unfair and cause hardship for the elderly and those on pensions." A substantial majority (65\%) agreed with this statement, whereas only two percent believed that it would "go too easy on them."

It is important to note that Americans feel this way despite the fact that resentment of their tax burden has increased between May 1978 and March 1981. However, of three types of taxes (federal income tax, property or real estate taxes, social security taxes) most resentment was expressed against the federal income tax. Fifty-two percent thought them "excessively high" as opposed to the lowest level of resentment against social security taxes (36\% "excessively high"). In contrast, only 16 percent of respondents believed federal income taxes were "about right" compared to 33 percent who believed this for social security taxes.

A resounding proportion (85\%) of those surveyed in May 1981 agreed that social security benefits should not be reduced, although this group split on how best to secure the finances of the system. The overwhelming majority (68\%) agreed that "social security benefits should be protected at all costs even if money has to be taken from other government programs," while another 17 percent agreed that this 
should be done by an increase in social security taxes. When given a choice between reducing benefits or raising taxes to solve the financial problems of the system, 55 percent of respondents favored raising taxes compared to 27 percent who wanted to cut benefits. Another poll revealed that Americans, when given a choice between higher social security taxes or limiting benefits, preferred to limit benefits $(46 \%)$ to raising social security taxes $(26 \%) .^{6}$ Other findings of public opinion polls revealed that 67 percent opposed Reagan's plan to reduce benefits for people who retire early, 68 percent opposed increasing the retirement age from 65 to 68 , and 70 percent opposed reducing benefits for future retirees. $^{7}$

A further complication also operated against immediate and drastic change. The myth of the Social Security system as a contributory social insurance policy (Kreps, 1980; Hollister, 1980) makes support a right (an entitlement) rather than a privilege. Given this consistency and depth, the public's current attitude precludes the possibility of drastic change in the relationship between the state and the elderly, an attitude shift that can be dated from the political movements of the 1920 s and 1930s, and the new ideological consensus worked out during the New Deal and strengthened during Lyndon Johnson's "Great Society." 8 This example suggests the second major element of any adequate theory.

\section{Social Organization}

The way in which society is organized is a determinate consideration. People orient their conduct to the institutional arrangements within any particular society. Among the institutions with the greatest degree of influence on individual conduct in industrial societies, certainly the economy and polity, the political economy, shape the content of a number of intermediate institutions such as mass media, the educational system, religion, science, the community, as well as family life. Wedded to the social organization of any society is a corresponding set of beliefs, attitudes, and values, that are both social (intersubjective), and individually held. These ideal conditions could be labeled "culture" as long as one recognizes that such a concept cannot be hypostasized from the material conditions to which it is directly linked in a dynamic way. In other words, the relationship between material and ideal conditions should be viewed as one in which there is always some general correspondence, but rarely, if ever is this correspondence complete. ${ }^{9}$ I consider the question of social organization the single most important element around which research must be oriented, although this element must remain closely connected to the historical perspective if it is to avoid the pitfall of what C. Wright Mills (1959) termed "abstracted empiricism."

\section{Life-Course Dimension}

The third element shifts the level of analysis from "macro" historical and social structural foci to the individual, although the social structural significance should still be apparent. It may appear superfluous to remind researchers that life does not begin at age 65 , but unfortunately a good deal of gerontological research has been conducted as if there was no link between a person's life before and after some arbitrary age. Any conceptually adequate study of the elderly must take the entire life-course into consideration as a key to the interpretation of the aging experience. Most research in social gerontology that has attended to the life-course has focused on psychological or personality traits, a reflection of its origin within the discipline of psychology. Leonard Cain (1964) was the first to identify the relevance of social aspects of the life-course as an important concern, but until the mid-1970s little sociological research had been conducted with this focus. Cain identified a number of factors that change over the lifecourse including family life, work, religious activity, political behavior, legal status, and agents of socialization. Of these, work and family processes over the life-course are the two most promising research areas that can add to our understanding of aging because these activities are the primary referents around which people construct their lives. However, as the social fallout of the world-wide recession of the last few years has revealed, work and family life are greatly influenced by developments in the political economy. It is only after the researcher has settled accounts with these first three elements that the fourth element can attain its full meaning.

\section{Individual Adjustment}

As important as this issue is, it has been the focus of research for too long. This element must be conceived in its relationship to the other three elements if social gerontology is to deal with causes rather than effects, and transcend documentary, descriptive studies. It is not enough for research to describe some aspect of an elderly person's lifesituation (i.e., how particular individuals adapt or adjust, or feel about their current life satisfaction or morale) without linking this information 
to the larger question of what this reveals about the system in which the elderly are embedded. One need not see the elderly as automatons that react mechanically to the system. In other words, a deterministic view of life should be rejected. Individuals react to similar situations in different ways, hence the question of how individuals "adjust" is important, but an attempt should be made to identify the social context of both the forces that require "adjustment" and the individual response. ${ }^{10}$

\section{THEORIES OF AGING}

I believe that theoretical developments in social gerontology point to the synthesis I have suggested, although each of the theories have emphasized only one or two of these elements. ${ }^{11}$ In this section I will show how the elements I have discussed were derived from previous theoretical formulations. I am aware of eleven theories in social gerontology that purport to explain the experience of aging. Activity, disengagement, personality (continuity), social breakdown, social-clock, minority-group, subculture, age-stratification, exchange, dual labor market (political economy), and phenomenological (social interactionist) theories have all been offered as explanations for the aging experience. Of these, only two are true special theories of aging. These are activity and disengagement theories.

The oldest theory of aging is activity theory. It was developed during the early period of social gerontology by psychologists and sociologists working with concepts current in American social psychology. The first major work of social gerontology, Personal Adjustment in Old Age (Cavan et al., 1949), borrowed concepts from psychology, and rested upon an implicit activity orientation. The very definition of "personal adjustment," and the way in which the concept was operationalized revealed two values that the authors believed should be the criteria by which to judge adjustment to the aging process. According to the authors:

Personal adjustment to ageing, or to other changes in one's self or environment, may be defined as the individual's restructuring of his attitudes and behavior in response to a new situation ... to integrate ... his aspirations with the expectations and demands of society. (Cavan et al., 1949:11)
Although the authors also recognized the concept of "social adjustment," in which society is restructured to meet individual needs, this concept was simply mentioned without further elaboration. The "conformist" nature of this definition of personal adjustment should be apparent. The well-adjusted individual was "flexible" (1949:14) and could change aspirations, expectations and demands to conform to the demands of society.

The operationalization of the concept of personal adjustment was equally suspect since it sought to measure the degree of conformity, and the level of activity of the older person. Operationalization of the concept resulted in the formulation of two inventories, one of which sought to measure subjective evaluation of life-satisfaction (the Attitude Inventory), and the other an objective measure of the degree to which each individual participated in activities believed to be "normal" for the elderly age group (the Activity Inventory). ${ }^{12}$

Activity theory remained more of an assumption than an explicit theory of aging until Elaine Cumming and William E. Henry (1961) first challenged the received view with their formulation of disengagement theory, a revised version of which Cumming (1963) offered in response to some of the criticisms leveled at disengagement theory. This led proponents of activity theory to formalize the tenets of their approach in reaction to this challenge. Cumming and Henry proposed disengagement theory as a formal theory and presented it as a series of testable propositions. The same degree of formalization of activity theory did not occur until 1972 when Lemon et al. (1976) tested this theory on a convenient sample. ${ }^{13}$

Activity theory and disengagement theory are mirror images of each other. Both purport to be universal theories. In other words, both theories maintain that they can explain the aging process for any society in any historical period. Both theories emphasize "personal adjustment" to the aging experience as crucial and link this to a concept of "successful aging." Both also focus on role loss as the stimulus for making adjustments. For both theories the aging experience is one that requires the individual to adjust to changing physical, mental, or societal conditions. The only difference is that activity theory maintains that the person who remains active by finding compensatory activities is happier (i.e., ages successfully), whereas disengagement theory maintains that the person who voluntarily disengages from society will be the "successful ager." Details of the controversy between disengagement and activity theory are documented by Harold L. Orbach (1974), and 
Mid-American Review of Sociology

cannot be dealt with here except to point out that evidence used in the controversy came primarily from one source; the Kansas City Study of Adult Life. Ironically, this massive study was also the basis of personality theory, the third orientation to emerge in social gerontology.

Personality theory (or continuity theory) is important because it provides evidence to reject both disengagement and activity theories as adequate and mutually exclusive theories of aging. In brief, personality studies, of which Havighurst (1976) and Reichard et al. (1962) are good examples, identified several personality types that were disengaged and several that were active, and showed that life satisfaction/ morale was possible for "active" as well as "disengaged" people. The advance that these personality studies brought about was the integration of studies of the aged with studies of the life-course, since the basic premise of personality studies was that each individual develops a personality over the course of a lifetime that is a stable feature of their individuality, which affects how they react to events. The basic thesis is that individuals attempt to maintain personality continuity as they age. Social breakdown theory, proposed by J.A. Kuypers and V.L. Bengston (1973), can be subsumed as an aspect of personality theory since it seeks to explain how personality continuity in terms of personal efficacy, competence and self-concept, can be undermined through unsuccessful encounters and experiences in the life-world. ${ }^{14}$

The fourth major theoretical development, social-clock theory (associated with Bernice Neugarten et al., 1980), carried the focus on the life-course dimension further when it documented the existence of age-norms. The clock analogy refers to whether or not the individual is "on-time." The authors conceived of age norms and expectations as a "system of social control." The implication is that one ages successfully if one is "on-time" and that sanctions (which were identified as "ageconstraints") would be applied if one did not "act one's age." The authors' conclusions suggest that the elderly are more likely than other age groups to see this system of age norms as legitimate and binding:

$[P]$ ersonal belief in the relevance and validity of social norms increases through the adult life span and . . . as the individual ages he becomes increasingly aware of age discriminations in adult behavior and of the system of social sanctions that operate with regard to age appropriateness. The middle-aged and the old seem to have learned that age is a reasonable criterion by which to evaluate behavior, that
An Adequate Theory of Aging

to be "off-time" with regard to life events or to show other agedeviant behavior brings with it social and psychological sequelae that cannot be disregarded. (Neugarten et al., 1980:168)

The authors seem to suggest that compliance with age norms is not an historical artifact of a particular society at a particular point in time, although they do recognize that the content of age norms and expectations are bound to a particular historical and socio-cultural context. In short, these authors imply that individuals in all societies come to accept the age norms of their particular society as they age. ${ }^{15}$ In maintaining this the authors have introduced a universal phenomenon into the theory.

The early 1960 s witnessed the promulgation of two theories that emphasized another element previously ignored when minority group theory and subculture theory were offered as explanations of the aging experience. Both attempted to move beyond the focus on the individual, the loss of roles, and one's adjustment to the "inevitable." What both of these theories sought to do was to introduce social structural variations as the determinant element in social gerontology. Minority group theory, first suggested by Milton L. Barron (1953), and subsequently adopted and brought into theoretical discourse by Leonard Z. Breen (1960; et al., 1961), maintained that aging individuals could be consid ered a minority group like any other, suffering similar consequences such as stereotypes and discriminations. This theory was criticized by Gordon Streib (1965), using criteria propounded by Louis Wirth. Streib maintained that the aged were not a minority group because their status was not permanent and exclusive, and it has since been dropped. from serious consideration as a theory of aging. This criticism of minority group theory on technical grounds cannot detract from the advance made by the recognition that society is an important consideration in explaining the position and status of the elderly.

Subculture theory (Arnold M. Rose, 1965) can be seen as a re finement of minority group theory, avoiding the pitfall of the difference between achicved and ascribed status (Streib's critique) yet retaining the notion that the position of the elderly could not be understood simply as an individual occurrence but affected the group as a whole. Rose theorized that three major trends within the United States -"demographic, ecological, and social organizational" in nature-would result in the formation of a subculture of the aging because the elderly 
have a "positive affinity" for their age peers based upon "physical limitations," "common role changes." and "common generational experiences," and their exclusion from interaction with other age groups. Although Rose recognized a number of influences that would retard the development of a subculture of aging, the factors that tended to promote the growth of a subculture were believed to be more powerful than the factors that integrated the elderly into society as a whole. These trends would eventually result in the formation of an "aging group consciousness," the sine qua non of the existence of a subculture. The defect of subculture theory is that proponents have been unable to substantiate its most important element, the existence of an old age group consciousness (Longino et al., 1980), despite continuation of the trends Rose identified as necessary for the creation of a subculture among the elderly. Most elderly, particularly middle-class elderly, do not identify with their age peers, nor has political necessity served as the catalyst for age group consciousness as of yet.

The next major theoretical development was Matilda White Riley's (1971) formulation of age-stratification theory. This was a major advance because it explicitly recognized the importance of history for social gerontology. Her major thesis was that the experience of aging is different for each cohort because of two important "dimensions of aging." The first she called the "life-course" dimension, which was conceived in terms of the roles one has experienced; student, spouse, parent, worker, etc. The second dimension she called the "historical dimension." Here, historical particularity was integrated into social gerontology as an important element of any adequate theory. Riley. acknowledged that Karl Mannheim (1952) suggested this in his "Problem of Generations," but his insight had little impact on the field until Riley emphasized the significance of historical events such as the Great Depression, World War II, Civil Rights movement, and Vietnam, in the formation of different cohorts. Both the life-course dimension and the historical dimension were important and tended to make people cohort-centric, or produce an affinity on the basis of shared experiences. ${ }^{16}$

The next two theories of aging have both been offered by James J. Dowd: exchange theory (1975) and dual labor market theory (1980). Exchange theory was the most thoroughgoing attempt to deal with the question of inequality (differential experiences) among the elderly when it was first introduced. In essence, exchange theory recognized that society is stratified on the basis of differential power (in terms of the control of resources) and the quality of one's experience and life chances are directly related to the amount of resources one controls. Exchange theory views all human interaction as an ex change of resources, either real or symbolic, and literally everything is a medium of exchange. According to exchange theory, the most powerful actors always benefit from the exchange. Since the elderly control few resources (aging is characterized as a period of declining resources), their situation is one in which they are at a disadvantage vis-à-vis society, social groups, and most individuals.

Exchange theory posits that individuals attempt to maximize or at least maintain their resources. To do this each individual attempts to keep exchanges "in balance" and this leads each individual to employ one or more of four "balancing operations." Individuals can 1) withdraw from exchange relations that are too costly (this operation conforms to disengagement theory), 2) extend their network by finding new resources (fits activity theory since the individual seeks compensatory resources such as work after retirement), 3) experience a reemergence of resources (this is not the result of individual effort but caused by societal change so that obsolete skills are once again important, as for example, knowing how to feed oneself if modern market society collapses), or 4) engage in coalition formation. Here, the individual seeks the extension of a power network (similar to subculture theory) through group solidarity and political pressure for better exchange rates for the group as a whole. The Townsend movement and the demand for financial support in old age would be an example of coalition formation.

There is much to quarrel with in this conception of society, but exchange theory is an important heuristic device. One can make use of exchange theory to understand the difference between the elderly with and without resources, and also predict what it will be like to age with or without resources. Although this theory was an advance in viewing the stratification of society as the most important element, it was a retreat from history. Dowd offered exchange theory as a universal theory, and exchange relations as the model of human interaction in all societies and eras. This is a terrible mistake and does not recognize the historicity of the theory itself. Viewed historically, exchange theory is appropriate only for capitalist societies that are in the process of thorough rationalization (i.e., where interpersonal relations increasingly take the form of calculated exchanges, and interpersonal relations become just one more extension of market relations). ${ }^{17}$ 
Since 1975, Dowd has moved to make exchange theory "historical" by "integrating" it with what he has called the "dual labor market" theory of aging. By adding the "dual labor market" approach to exchange theory Dowd has attempted to explain both structural and individual social processes. He uses exchange theory to explain individual interactions, and the dual labor market perspective to account for the accrual of unequal resources by particular groups of individuals. This is a syncretic effort that attempts to join a thoroughly bourgeois explanation of individual interaction with a structural interpretation derived from neo-Marxist analysis of a particular political economy (i.e., the United States). This formulation is inadequate because it contains this deep contradiction, and is "historical" solely at the structural level of analysis for a single political economy at a particular point in time. Despite these flaws, Dowd's introduction of the dual labor market thesis is an important theoretical consideration when dealing with the United States, if one ignores the exchange portion that Dowd retains. ${ }^{18}$

In brief, Dowd maintains that whether or not one ages successfully depends on one's position in the political economy. He divides the economy into two sectors; a monopoly sector and a competitive sector. Where one works determines what one can expect old age to be like. If one works in the monopoly sector one is likely to age successfully because of higher lifetime wages, private pensions, medical and other fringe benefits-in short, the accrual of more resources that serve to buffer the vicissitudes that most elderly can anticipate at some point in their life (although the timing is highly variable). For Dowd, the accrual of resources allows one to be a powerful exchange partner even in old age. On the other hand, if one works in the competitive sector one can expect just the opposite. ${ }^{19}$

Other efforts to define a political economy of aging approach can be found in Walker (1981) and Estes et al. (1982). ${ }^{20}$ Both characterize aging as the "social creation of dependent status"' (Walker, 1981:75). This approach challenges the pervasive view that individuals are wholly responsible for or create what they experience in old age. According to Estes et al.:

In contrast, the structural view of ageing starts with the proposition that the status and resources of the elderly, and even the trajectory of the ageing process itself are conditioned by one's location in the social structure and the economic and political factors that affect it.
The dependency of the elderly is to be understood in the labour market and the social relations that it produces ... as they change with age. (1982:4)

Although there is a great deal of agreement between Walker and Estes et al., there are important differences in emphasis. Walker, like Dowd, has focused on the individual's position while a participant in the labor market as the primary factor that determines what old age will be like. The individual's participation in the labor market is also important to Estes et al. However, they also stress that the dependent position of the elderly is attributable not only to their past position in the labor market but to their present position as the raw material and finished product of service oriented economies. This theme of the creation of a "special" dependent status through social policies developed and expanded in response to the employment needs of a declining industrial, increasingly service oriented economy is discussed at length in Estes' earlier work (1979b). In a succinct statement of the implications of this insight for research on aging, Estes et al. cautions that:

any analysis of class and age must concern itself with how the aged, whatever their previous background, are made dependent upon an ageing enterprise and its agents, as well as how the aged are made differentially dependent according to their post-retirement class status. (1982:8)

Although the importance of the historical and life-course dimensions are implicit in the political economic approach advanced by these. authors, they are either left as assumptions or mentioned in passing. Neither Walker nor Estes state that one must limit oneself to a discussion of a particular political economy, although most of Walker's analysis is about Britain and Estes et al. discuss the United States. Both also appear to reduce investigation of the life-course to work through the life-course. Furthermore, both neglect to define class in a way that can be studied empirically. Despite current shortcomings, I believe that a political economic approach will yield the best understanding of what any particular individual is likely to experience when aging.

The last theory I wish to discuss, phenomenological or social interactionist theory, has only recently begun to attract attention in theoretical discourse in social gerontology, although a great deal of participant observation research has been conducted with an implicit 
phenomenological basis. Perhaps the best examples of a phenomenological theoretical perspective can be found in Jaber F. Gubrium's $(1972,1973)$ formulation of what he called a "socio-environmental theory" of aging or Victor W. Marshall's (1981) "symbolic interactionist" perspective. I consider both theories phenomenological because both explain the aging experience as bound to the specific situation or context in which the elderly live. As a method, phenomenology has yielded valuable results grounded in the empiricism of the everyday life-world, as Gubrium (1974), Marshall (1975), or Andrea Fontana (1980) have shown for different living environments. As a theory, however, pure phenomenology has one crucial limitation. Adherents of this theoretical perspective maintain that it is sufficient to describe or transcribe an elderly person's self-understanding of the aging experience ${ }^{21}$ (i.e., the social construction of reality, situational definitions, negotiated order). For the phenomenologist, how the informants characterize the situation is accepted uncritically as the interpretation of the situation. What this leaves out is as important as the participant's understanding of the situation. A purely phenomenological approach does not attempt to evaluate whether the informants' understanding of the situation is accurate. In other words, a purely phenomenological approach succumbs to a dangerous form of naive empiricism. Quite simply, the participant's estimation of the situation can be wrong in two ways. First, as the example of old age stereotypes reveals, people can simply be misinformed in any number of respects. The second problem that phenomenology does not recognize is the problem of false consciousness, or a systematically distorted conception of reality. ${ }^{22}$

\section{CONCLUSION}

To the extent that one can characterize theoretical developments in social gerontology, the trend has been away from a search for a special as well as an universal theory of aging. It is wise to abandon these endeavors since any effort along these lines will remain fruitless as long as material and ideal conditions vary from country to country and over time. There has also been a shift away from a focus on the individual and viewing "the" elderly as a homogenous group to social processes that result in differential experiences and life chances as groups of aging individuals share a limited number of aging trajectories. At the same time, attention has shifted from a focus on the "aged" to the aging process, and from physiological or biological changes as primary determinants of the aging process to aging as a social phenomenon. These theoretical developments that I have discussed have moved social gerontology to the point where the theoretical prerequisites of an adequate theoretical approach to aging can be delineated. Any adequate theory that seeks to explain the aging experience must integrate the four elements or dimensions that have not yet been synthesized with any degree of completeness. The social organization of society, especially the stratification of society through the political economy, and knowledge of history are determinant issues for any understanding of the aging experience considered over the life-course as problems that require individual "adjustment." Such an holistic approach that attempts to provide an interpretation of individual experience within its historical context is the appropriate goal of theory.

\section{FOOTNOTES}

1. One could argue that a special theory is undesirable for a number of reasons. The only constant in the aging process is physiological change. However, the rate and onset of change varies from person to person. Social gerontology has been moving away from physiologically based explanations of the aging process since research began to discover that the aging experience is not strictly determined by biology. For instance, if one suffers a stroke that impairs mobility, the significance of this physiological occurrence is overshadowed by the social context in which this physiological fact occurs. The meaning of the event for one's life or the extent to which one becomes disengaged or remains active is less the consequence of the stroke than of the types of resources and cultural attitudes that prevail in any particular society. Among the types of resources that alter the meaning of suffering a stroke are timely and adequate medical care, rehabilitation therapies, availability of devices that assist mobility, struc tural access to public and private facilities, community transportation designed to accommodate disabled people, the level of public and private financial support relative to living costs and the costs of necessary services, just to mention some of the potential resources a society could make available. In addition to these material resources, the attitudes of people toward the disabled, and societal values (whether "independence" is valued and "dependence" denigrated) make a difference in how the stroke victim perceives their disability. It should be apparent that the psychological attitude of the stroke victim is not derived from the physiological condition but from the social context of the physiological condition. In other words, there is no direct link between physioogical condition, and the meaning, social or psychological, attached to that condition. 
Another objection to a special theory of aging is the tendency for special theory of aging to become a special theory of the aged. This has had the undesirable effect of shifting gerontological research from dealing with a lifelong process to the contrived and narrow range of years between leaving the labor-force and death. A number of social gerontologists have cautioned against the notion that elderly people are a homogenous group. One of the most in fluential challenges to this idea, which has gained popular acceptance, is Bernice Neugarten's (1974) distinction between the young-old and the old-old. Part of the purpose of this essay is to suggest a typology for the United States that further delineates the bases of heterogeneity among elderly individuals.

2. The theoretical quest can never result in settling the question of knowledge once and for all. Reinterpretation is the nature of the theoretical enterprise and the essence of knowledge. In making this statement I rely on the authority of Max Weber and his epistemology of the cultural sciences. Here I have made explicit for social gerontology a point that Weber argued was true of all the cultural sciences. History, seen as changing value stances, leads to new concerns and reinterpretations of the social world. I refer the reader to one of Weber's earliest essays on the philosophy of the cultural sciences published in 1904 and referred to as an authoritative statement in Economy and Society (1978: 22), for confirmation and elaboration of the ideas I can only acknowledge in passing. Weber stated with characteristic compactness that the "points of departure of the cultural sciences, remain changeable throughout the limitless future. . . . A systematic science of culture, even only in the sense of a definitive, objectively valid systematic fixation of the problems which it would treat, would be senseless in itself" $(1904: 84)$. See also $(1904: 104)$ on the "tran siency" of all concepts and (1904:112) for Weber's statement on how. new knowledge is achieved.

3. For this reason I will confine my remarks to the United States. In doing so I am implicitly arguing against the belief that "modernization" theory will result in the identification of any universal, cross-cultural process or pattern that reveals a relationship between social change and the status of the elderly, however these concepts are measured. Leo Simmons (1960) has shown that the elderly in so-called primitive societies were not universally accorded high status. Likewise, even in countries with apparent cultural similarities (such as contemporary Britain, Canada and the United States) the aging experience can be (I would suggest that it is) unique to each country.

These comments apply equally to those social gerontologists in search of a "world-systems theory of aging." Despite advances made in the identification of international linkages in the economic sphere, such a project applied to aging is premature and awaits the linkage of the political sphere on some international basis. Until then, each national political economy will continue to determine policy for the "elderly" in a relatively autonomous manner. Perhaps policy formulations of the modern industrial societies of France and the United States will serve as an example. In reaction to similar economic exigencies, the government of France has determined to shorten the work week and reduce the age of retirement while the government of the United States has not shortened the work week in 44 years (1940) and has enacted legislation to increase the age at which individuals can retire.

4. In identifying an historical orientation I do not mean to ontologize history as a "thing-in-itself." Rather, this historical orientation is a reminder that the material and ideal conditions that exist at any particular time are determinant, and are the ground for knowledge in any of the cultural sciences. This position is drawn from the work of Max Weber in which history provided the terms of Weber's concept of "objective possibility." For Weber, history is a possibility structure in which all societies are poised at the ingress of many possible paths. However, the possibilities are objectively determined by political-economic forces, technical development, and ideology; in short, a given, empirically discernable, set of material and ideal conditions. See footnote 9.

5. Partial results of a series of public opinion surveys have been published in the bi-monthly journal Public Opinion (August-September 1981:35-37; DecemberJanuary 1982:28-29), a publication of the American Enterprise Institute, a conservative think-tank not particularly sympathetic to increased government spending for social programs. The interpretation of these results that follows, however, is my own. Unless otherwise noted, survey results from which this interpretation is drawn can be found in the issues I have cited.

6. I think the most reasonable interpretation of these results is that Americans favor buttressing social security through use of general revenues rather than a rise in social security taxes. Although income taxes are more onerous in absolute terms for nearly all income groups, the social security tax is regressive and currently only the first $\$ 37,800$ of income is subject to taxation. In 1984 , the Social Security tax rate for wage workers was 7.0 percent on the first $\$ 36,000$ of income. The tax rate is scheduled to rise to 7.65 percent by 1990 . Americans' relative lack of resentment for the social security tax may well stem from their belief that it is merely "forced saving" for their future retirement.

7. Despite general opposition to these three changes, Reagan did manage to change the retirement age, the age at which a person can retire with full bene fits, and, in that sense, reduced benefits for future retirees who were born afte 1938. For people under 45 years of age, the 1983 Social Security Amendments mandate a gradual increase in the retirement age from 65 to 67 (most people born during the post-World War II baby boom cannot retire with full benefits until they reach age 66), and although 62 remains the earliest age at which a person can retire and draw Social Security benefits, people who choose to do so will suffer a reduction in benefits. Currently, a person who retires at 62 receives 80 percent of the amount payable at 65 . Under the new provisions, a person retiring at age 62 in 2022 will receive 70 percent of the benefit payable at age 67.

In fact, the only portion of Reagan's proposed changes that had wide acceptance was the removal of the earnings limitation that reduces benefits if 
recipient makes more than a certain amount of money in a given period of time. In 1983, people between the ages of 65 and 69 could make $\$ 6,600$ per year while people under 65 could make $\$ 4,920$ without having their Social Security benefits reduced. People over age 70 are now exempt from these earning limitations. A public opinion poll taken prior to the 1983 Socia Security Amendments found that 71 percent of respondents favored a change in the earnings limitation, although this type of exemption greatly favors professionals and the self-employed rather than wage workers. Another change that people favor, although not one directly attributable to Reagan, is the elimination of mandatory retirement. Ninety-one percent of respondents agreed strongly or mildly that no one should be forced to retire if he or she wants to continue working.

Despite the fanfare surrounding the issue of balancing the federal bud get, when Americans were given the choice between balancing the federal budget if it meant "sharp cuts" in federal aid to the "elderly, poor, and handicapped" 83 percent favored not balancing the budget. This last question provided what may easily be dismissed as an overly broad range of groups designed to elicit a sympathetic response, but when asked specifically whether they favored balancing the budget if it meant "sharp cuts for social security," 78 percent favored not balancing the federal budget. Of the other programs for which this same question was asked (federal health programs, federal aid to education, defense spending, and the food stamp program) only the food stamp program was viewed (by $65 \%$ ) as an acceptable source of funds by which to balance the federal budget. Opinion was split on cuts in defense spending to balance the federal budget ( $49 \%$ for cuts, $51 \%$ against) but all other programs for education, health, social security, and aid to the elderly, poor and handicapped received support from a clear majority.

What makes this support for social security all the more overwhelming is revealed by a factual question to which people were asked to respond. It is most interesting as a measure of the individual American's suspicion of "bloated" federal bureaucracies. When asked, "Out of every $\$ 100$ of Social Security taxes taken in by the Social Security Administration, about how many dollars do you think go to pay for administration costs rather than to actual benefits paid out to recipients?" The median response was $\$ 52.10$. The actual administration costs for 1980 were $\$ 1.30$ Only two percent of Americans responded correctly that administration costs fell in the range from $\$ 0-9$. Despite their erroneous belief that over half of everything collected goes to support bureaucrats, people continue to support the system by a significant margin.

Further scrutiny of public opinion reveals equally interesting results. Although 56 percent of respondents favored making social security voluntary, 75 percent said they would participate. A New York Times/CBS poll (New York Times, July 17, 1981, p. 12-A) revealed that 45 percent of their respondents said they were "covered by no other pension or retirement plan." Of those 65 and over, 47 percent said they were covered by no other plan. Breakdowns by income and race are also relevant to the class interests involved in the political struggle over social security. Fifty-seven percent of blacks compared to 44 percent of whites said they were covered by no other plan. The breakdown by income is as follows:

INCOME
Under $\$ 10,000$
$\$ 10,000-20,000$
$\$ 20,000-30,000$
$\$ 30,000-40,000$
Over $\$ 40,000$

NO OTHER PLAN
$68 \%$
$48 \%$
$34 \%$
$29 \%$
$35 \%$

8. It is interesting to see how Reagan has attempted to defuse this explosive political situation from the very beginning of his term in office. A great deal of controversy surrounded the 1981 White House Conference on Aging. The Reagan administration was accused of attempting to restrict debate and devised a set of rules for the conference that would not permit the adoption of policy recommendations unfavorable to his political goals. Despite the fact that Reagan did manage to force adoption of the conference proposals produced by the various committees on an "all or nothing" basis, enough minority reports were issued to make it clear that aging policy presented more than a routine problem of political management. In May 1981, Reagan unveiled his solution to the "crisis" in the social security system and quickly had to de-politicize the issue because of immediate, widespread opposition. Fearing that this issue could well be the political albatross that would be his undoing through substantial mid-term election losses, Reagan formed the National Commission on Social Security Reform to study the problem and report its recommendations after the 1982 Congressional elections. It is my belief that this did succeed in "cutting his losses," although "liberal" democrats made modest, yet significant gains that did knock Reagan "off course." In the 1984 presidential election, Reagan was at great pains explaining his policy on Social Security whenever he was forced to deal with the issue. His response was to deny responsibility for the changes and shift the blame to the Democratically-controlled House of Representatives. Reagan's unequivocal campaign pledge to protect Social Security from further cuts appears to have withered in the two months between the election and the convening of Congress since some Republican congressmen have said that Social Security cuts will be necessary no matter what Reagan promised.

A strategy similar to the one used to bring about changes in Social Security has been pursued on the issue of changes in the Medicare program. Al though important changes have been implemented with little public attention (Walker, 1983), major revisions have been postponed until after the 1984 Presidential elections. It is clear that a decisive legislative battle looms over this entitlement program since the same kind of "crisis" rhetoric has characterized the context in which this issue has been discussed whenever politicians have been forced to respond during the recent campaign. This program will be major target of the budget cutters now that Reagan has been reelected and the Republicans have retained control of the Senate and gained seats in the House of Representatives. With or without Republican majorities, this will be 
difficult political issue to resolve, although further reductions of Medicare benefits appear "inevitable" since there seems to be little likelihood that the capitalist organization of medical care will come under assault through strict federal regulation of hospital costs and physicians' fee schedules.

9. I am seeking to avoid the twin pitfalls of the reflection theory of knowledge (that knowledge is simply a reflection of the material conditions of society) and the idealist or intuitionist theory (that ideas are independent of the material conditions). Both Marx, in the "Theses on Feuerbach," and Weber reject these theories of knowledge. Weber $(1946: 280)$ stated the relationship between material and ideal conditions in this way. "Not ideas, but material and ideal interests, directly govern men's conduct. Yet very frequently the 'world images' that have been created by 'ideas' have, like switchmen, determined the tracks along which action has been pushed by the dynamic of interest."

More concretely, however, this lack of correspondence between the material conditions and ideas people have about these conditions are documented in the social gerontological literature on ageism or stereotypes about aging individuals. Although these widely held stereotypes are true for a small proportion of elderly people, they are quite easily shown to be a popular misconception about most people of advanced age. The findings of these studies are consistent. Most people, including elderly people themselves, have a shared set of negative stereotypes about aging individuals. For instance, despite positive evaluations of their own physical, mental, and social capabilities, when asked about other people their own age, elderly people subscribe to all the negative stereotypes of aging held by people younger than themselves. An argument that suggests that this is attributable to "pluralistic ignorance" misses how such stereotypes have been socially created and perpetuated. For a few examples of attempts to identify and debunk these myths and stereotypes see Butler, 1975:6-16; Hess, 1980; Harris, 1975; or Sheppard, 1981.

10. Perhaps the best example to illustrate this point can elaborate a point made earlier. The reduction of living standards in the United States during the most recent recession (through unemployment, inflation, wage restraints, contract concessions, etc.) has forced individuals to "adjust" to less. But the forms that "adjustment" takes are related to one's position in the life-course (it is more difficult for an unemployed worker to find work if he or she is 55 rather than 25 , the historical trajectory of the national political economy (it is more difficult to adjust if one is an industrial worker rather than a worker in the service sector), or whether one is a minority, or a woman.

11. With the exception of Cumming and Henry's (1961) formulation of disengagement theory and Lemon et al.'s (1976) formulation of activity theory, most theories in gerontology have not been stated as an integrated set of formal, testable propositions. The theoretical framework that I propose is not amenable to the kind of formalization that Cumming and Henry, and Lemon, et al. attempted. For those who believe that formal theory is the goal of the social sciences I can only point out that every researcher does, in fact, take a position in regard to the four elements I have identified, no matter what one's conscious orientation to the questions I have raised may be. For example, research that concentrates solely on an aspect of the aging experience among people designated as "elderly" necessarily assumes that any thing that happened before (i.e. over the life-course) lacks relevance for the problem. Likewise if one seeks to identify and test propositions that one believes to be universally valid, one assumes that history and "culture" are unimportant. Much research has also been conducted without sufficient attention to social structure. If a researcher seeks to characterize the family of later life but only samples middle-class subjects, or if one seeks to determine personality types among the elderly but only studies males, untenable assumptions about the homogeneity of the social structure have been made which severely restricts the significance of the results.

12. The study by Neugarten, Havighurst and Tobin (1976), first published in 1961, was one of the first to question the inventories constructed by Cavan et al. (1949). These researchers formulated several alternative indices that were very influential in the direction of life-satisfaction/morale research. The question of life-satisfaction/morale has been a major focus within social gerontology since its inception, and a good analysis and overview with a lengthy bibliography of this literature can be found in Reed Larson (1978). Larson raises a number of questions about these studies; the validity of cross-sectional studies, the problem of aggregate data in revealing anything about the life-satisfaction of particular individuals, the differences that exist between subgroups of the population, and the implicit assumption that the independent variables used to measure well-being are related in a linear fashion as most researchers have assumed; but stopped short of rejecting any particular measure or index. Danny R. Hoyt and James C. Creech (1981) have followed several of the suggestions made by Larson and tested three of the most widely used lifesatisfaction scales; the LSIA, LSIA-A, and LSIZ. These authors rejected each of these scales and tried to construct a modified scale using a subset of the items in the LSIA (Neugarten, Havighurst, and Tobin, 1976). This reformulation, however, was considered only moderately successful. The authors concluded that researchers should no longer use scales based on the LSIA, and suggested that research focus on the life-course as well as important social structural variations between individuals, particularly race and class. I have also interpreted the authors' conclusions to suggest that life-satisfaction/morale itself probably changes over time, and that any "static" measure of life-satisfaction is inappropriate. For an earlier test of the Life Satisfaction Index A and activity theory see Danny R. Hoyt et al. (1980).

13. This paper is an attempt to deal with one of the two major problems with social research. My primary remarks are directed to a critique at the conceptual level of research design. The other major problem with research in gerontology is that most of the results are based upon "convenience" samples or employ secondary data that are not suited to answer important questions. To say that 
samples are biased or unrepresentative is insufficient. The shortcoming of a great deal of research exhibits some combination of conceptual or sampling errors. Some have argued that this, in turn, has led to the addition of so much "noise" to the field that it is hard to say what has been accomplished in the last thirty-odd years. Recognition of this has lead one doyen of social geron tology to call for taking stock of "what we really know" about the aging expe rience. These comments were made at the Midwest Council for Social Research in Aging seminar, Kansas City, January, 1982, by Matilda White Riley, but similar sentiments can be found in Riley $(1980: 341)$ on the paucity of research that has met "minimum criteria of empirical validity."

14. A recent theoretical statement of continuity theory (Herbert C. Covey, 1981) has shifted the focus from personality continuity to role continuity. Covey believes that we will learn something about role continuity by looking at how certain individual characteristics (such as socioeconomic status and personality) intersect with "sociocultural" factors that "vary from society to society" and "vary over time" (1981:629). Unfortunately, Covey has suggested that historical and social structural elements need to be considered as important in fluences on the individual life-course without explaining how it is that these elements should be considered. The problem is that Covey discusses and reduces these sociocultural factors to three concepts: "age-grading, ageconcepts and age-stereotypes." He goes on to state that the "social structural factors account for the homogeneity of the aging process.... [ $t]$ he individual social characteristics account for the heterogeneity" $(1981: 630)$. This is an interesting statement but hardly touches the issue of the role of the state or the economy, much less the intermediate institutions, and how they influence the range of alternatives or outcomes open to individuals. The most suspect portion of Covey's formulation is his apparent assumption that whatever happens to the elderly is "functional and efficient" and his conception of the relation ship between the individual and society as a "balance." At its root, Covey's theoretical orientation is an antiquated version of American structuralfunctionalism.

15. Victor Marshall (1981) has criticized all theoretical approaches to aging based on the sociological paradigm that is concerned with questions of order and conformity in society. This normative bias (with its corollary "deviance") is evident in much work in social gerontology, whether the experience of aging is explained as the result of inadequate socialization, the lack or loss of definite roles (roleless role), or the interplay of age norms and age constraints. Marshall emphasizes that this paradigm neglects the individual as a subject attempting to control the creation of meaning each attributes to their experience, thus preserving a sense of autonomy. This process suggests a life-world that is constantly constructed and negotiated as opposed to the rigid model implied by "age norms" and "age constraints," with its monolithic view of "normalcy" and "deviance."

16. Riley's latest work (1980) is a disappointment because she has begged the most important question that she herself has posed for social gerontology. If history is important, how can we use history to define or delineate cohorts in a meaningful way? If historical change is taken seriously, studies that define cohorts on the basis of 10,15 or 30 year intervals commit the worst kind of naive empirical assumption. Researchers need to conduct studies that seek to determine how history can delineate separate cohorts. Riley has suggested that major events are important but other indicators should also be used to identify particular cohorts, such as musical tastes, leisure activities, age range of social contacts, and attitudes toward a number of issues, just to suggest a few possibilities. Another failing of the research on cohorts has been the focus on events to the exclusion of processes, whether such processes are characterized by increasing rationalization, or the needs and movements of capital (or any other organizing concept). Studies attentive to these issues may reveal something like a cohort mosaic composed of unequal sizes and shapes. Some cohorts may span a 15 year interval while another only 7 years. Researchers may also find that particular historical periods, the depression era for instance, may produce two or more distinct cohorts, thus grounding the notion of a cohort in history rather than the simpler a priori definition of "people of approximately the same age."

A good treatment of some of the conceptual and theoretical problems of cohort analysis can be found in Michael McQuaide and William Sauer (19.79). McQuaide and Sauer (1979:31) identify and question three primary assumptions of cohort analysis: that 1) like experiences produce like effects, 2) cohort effects make their imprint during critical periods of transition in the life-course of individuals, and 3 ) the effects of historical events are carried forward in time and are reflected in individual behavior. Two points made by McQuaide and Sauer need to be emphasized. First, the "effects of the sociohistorical environment vary not only on the basis of age, but also on the basis of sex, race, occupation, educational level, religious affiliation, and political ideology" (1979:35). Furthermore, these authors suggest that cohorts themselves change over time so that differences emerge and increase between people within the cohort, perhaps to the point where a cohort can no longer be said to exist.

17. Joan Aldous (1977) has criticized exchange theory as a way of understanding family life, a critique that I endorse. David Willer has pointed out that exchange theory totally neglects what Weber (1978:685ff) called "third party responsibility." More criticisms could be made but it should suffice to say that the theory is simplistic and reductionist. It presents an over-rationalized and barren concept of human interaction, and dismisses any sort of human virtue such as compassion or altruism as a satisfaction with meaning only on a psychological level as just another form of self-gratification. For exchange theory, the ideal social actor is one who coolly calculates his or her self-interest (narrowly defined) and is always scrutinizing the balance sheet to make sure that credits outweigh debits in relations with others. Although such devices as pre-nuptial agreements reveal the penetration of market relations, legal-rational predispositions, and an individualistic ethic into family life, conduct within the family remains grounded in the principle of generalized reciprocity. As Emma 
Goldman recognized: "If love does not know how to give and take without restrictions, it is not love, but a transaction that never fails to lay stress on a plus and a minus" (Alice S. Rossi [ed.], The Feminist Papers, 1973:515).

18. It is my belief that Dowd has not yet finished his theoretical quest. Once Dowd recognizes the incompatibility of exchange theory and the dual labor market theory a new theoretical formulation will be required. Dowd's (1980) Stratification Among the Aged must be viewed as a first approximation or transition between theoretical positions. At this point he is between his previous position (exchange theory) and where he appears to be moving ("Marxist" political economy). Because of this Dowd's book fails to address the crucial issue of what individuals are likely to experience (in the material sense of their life chances) in old age given their specific class position.

19. Beyond this general dichotomy of two broadly defined class divisions Dowd begs the question of how to differentiate and measure class. Harold M. Hodges (1968:79) identified four ways by which social class has been measured. These general approaches to social class are exhaustive, but how each has been operationalized has led to very different views of the existence of social class in the United States. One can measure social class by 1) style of life-including possessions and patterns of association; 2) what others think (the reputationa approach)-the class position assigned to individuals by other people; 3) how people identify themselves-consciousness of class and their own class position or 4) how people earn a living-occupation and sources of income. Of these, the subjective indicators of class (what others think and how people identify themselves) are of little use for the United States where class consciousness (along with ethnic identification) were early targets of the educational system, advertising industry, and political policies based on nationalism and class harmony, all of which characterize the United States in the twentieth century. Although social gerontologists have documented important differences in lifestyles (patterns of association with family and friends, political behaviors, social integration) they have measured class by occupation or, more commonly, income. According to Hodges, measuring class by life-style is "the most intricate and vexing of the measures" (Hodges, 1968:79).

The measure of social class that I propose is based on James O'Connor's tri-partite division of the labor market. Dowd acknowledged his debt to James O'Connor (1973) in his formulation of the dual labor market thesis, but Dowd failed to adopt O'Connor's own division of the economy into three parts. My correction would be to add the state sector that Dowd ignored since this sector employs roughly one-third of the labor force in the United States, and is very much like (if not better than) the monopoly sector in terms of financial advantage (wages and benefits). A provisional class matrix would be constructed according to one's location in the major sectors of the economy. An additiona category, composed of the unemployed (the lumpenproletariat, underclass, reserve industrial army, or life-long welfare recipients) and people (particularly women) who are outside or marginal participants in the labor force by "choice," is necessary to complete the typology. This is an attempt to refine the conception of class ultimately derived from Marx, in which class is determined by one's relation to capital. Even so, because of the complex nature of the stratification system in the United States, some ambiguity and contradictions of class position will persist (Wright, 1979; Giddens, 1973).

SECTOR OF THE ECONOMY

\begin{tabular}{|l|l|l|l|}
\hline STATE & COMPETITIVE & MONOPOLY & $\begin{array}{l}\text { RESERVE/ } \\
\text { REPRODUCTIVE }\end{array}$ \\
\hline $\begin{array}{l}\text { administrative, } \\
\text { professional } \\
\text { service } \\
\text { workers }\end{array}$ & $\begin{array}{l}\text { owners of } \\
\text { small } \\
\text { businesses, } \\
\text { professionals }\end{array}$ & $\begin{array}{l}\text { salaried } \\
\text { managerial } \\
\text { and technical } \\
\text { workers }\end{array}$ & $\begin{array}{l}\text { chronically } \\
\text { unemployed, } \\
\text { "housewives" }\end{array}$ \\
\hline $\begin{array}{l}\text { clerical, } \\
\text { custodial, } \\
\text { production }\end{array}$ & $\begin{array}{l}\text { non-union } \\
\text { minimum-wage } \\
\text { labor }\end{array}$ & $\begin{array}{l}\text { union wage } \\
\text { and farm } \\
\text { labor }\end{array}$ & \\
\hline
\end{tabular}

According to this scheme, an individual's income masks class rather than defines it. The historical and cultural specificity of this model drawn from the work of O'Connor should be apparent. It is conceivable in countries in which class consciousness is pronounced, France or Italy for example, that class could be measured subjectively.

20. Anne-Marie Guillemard $(1980,1982)$ has been a leading proponent of a political economy of aging perspective, especially the French case. Another work on the political economy of aging in the United States is by Laura Katz Olson (1982). Although a thorough presentation of the changing relationship between the political economy and aging policy, it is solely a social structural account. Despite the value of her work, she too has neglected to provide a means by which to investigate empirical class differences. My view is that the political economy of aging cannot stop at the social structural level of analysis. Researchers must show that the consequences revealed by a structural analysis are confirmed for the classes of individuals that have been theoretically identified.

21. Victor Marshall (1981:92) implies that there are constraints on the construction of reality when he states that "older people do not possess complete freedom to construct a world of their choice. . . To say that our world is a world of meanings is not to say it is a world of ideas alone." I interpret this to mean that a phenomenological account is an essential element that provides the researcher with knowledge of how aging individuals perceive and interpret their experience. The researcher does have an obligation to present this view but also must link this to the constraints in which individual lives are embedded. These constraints are summarized here as historical, social structural, and individual (through the trajectory of their life-course) in nature. 
22. Anthony Giddens (1977:175-178) has made a more extensive critique of ethnomethodology, which can be viewed as the most influential American version of phenomenological theory. In addition to the fallacy of the "incorrigibility of common sense" understandings of the world that I have focused upon, Giddens included the failure of ethnomethodology to recognize imbalances between actors in terms of "power relations." and the "reproduction of a series of structures" for the actor's "common sense" understanding of reality.

\section{REFERENCES}

Aldous, J.

1977 "Family interaction patterns." Annual Review of Sociology 3:105-135. Barron, M.L.

1953 "Minority group characteristics of the aged in American society." Journal of Gerontology 8:477-482.

Breen, L.Z.

1960 "The aging individual." Pp. 145-162 in Clark Tibbitts, (ed.), Handbook of Social Gerontology. Chicago: University of Chicago Press.

Breen, L.Z., et al.

1961 The Adult Years. Lafayette, IN: Purdue University.

Butler, R.N.

1975 Why Survive? Being Old in America. New York: Harper \& Row.

Cain, L.D.

1964 "Life course and social structure." Pp. 272-309 in Robert E.L. Faris, (ed.), Handbook of Modern Sociology. Chicago: Rand-McNally.

Cavan, R.S., et al.

1949 Personal Adjustment in Old Age. Chicago: Science Research Associates. Covey, H.C.

1981 "A reconceptualization of continuity theory: some preliminary Cumming, E houghts." The Gerontologist 21:628-633.

1963 "Further thoughts on the theory of disengagement." International Social Science Journal 15:377-393.

Cumming, E. and W.E. Henry

1961 Growing Old: The Process of Disengagement. New York: Basic Books. Dowd, J.J.

1975 "Aging as exchange: a preface to theory." Journal of Gerontology 30(4):584-594.

1980 Stratification Among the Aged. Monterey, CA: Brooks/Cole.

Estes, C.L.

1978 "Political gerontology." Society 15(5):43-49.

1979 a "Toward a sociology of political gerontology." Sociological Symposium 26 (Spring):1-27.

1979b The Aging Enterprise. San Francisco: Jossey-Bass.
Estes, C.L., J.H. Swan, and L.E. Gerard

1982 "Dominant and competing paradigms in gerontology: towards a political economy of ageing." Ageing and Society 2(2):1-11.

Fontana, A.

1980 “Growing old between walls.” Pp. 482-499 in Jill S. Quadagno, (ed.), Giddens, A.

1973 The Class Structure of the Advanced Societies. New York: Harper \& Row.

1977 Studies in Social and Political Theory. New York: Basic Books.

Gubrium, J.F.

1972 "Toward a socio-environmental theory of aging." The Gerontologist 12:281-284.

1973 The Myth of the Golden Years: A Socio-environmental Theory of Aging. Springfield, IL: Charles C. Thomas.

1974 "On multiple realities in a nursing home." Pp. 61-98 in Jaber F. Gubrium, (ed.), Late Life: Communities and Environmental Policy. Springfield, IL: Charles C. Thomas.

Guillemard, A.

1980 La Vieillesse et l'Etat. Paris: Presses Universitaires de France.

1982 "On the relationship between dominant sociological paradigms in the field of aging and welfare programs for the aged." Paper presented at the International Sociological Association 10th World Congress of Sociology, Mexico City, August, 1982.

Harris, L., et al.

1975 The Myth and Reality of Aging in America. Washington, D.C.: National Council on the Aging.

Havighurst, R.J.

1976 "Personality and patterns of aging." Pp. 192-199 in Cary S. Kart and Barbara B. Manard, (eds.), Aging in America. Port Washington, NY: Alfred.

Hess, B.B.

1980 "Stereotypes of the aged." Pp. 126-133 in Jill S. Quadagno, (ed.), Aging, the Individual and Society. New York: St. Martin's.

Hodges, Jr., H.M

1968 Social Stratification: Class in America. Cambridge, MA: Schenkman. Hollister, R.

1980 "Social mythology and reform: income maintenance for the aged." Pp. 419-439 in Jill S. Quadagno, (ed.), Aging, the Individual and Society. New York: St. Martin's.

Hoyt, D.R. and J.C. Creech

1983 "The life satisfaction index: a methodological and theoretical critique." Journal of Geontology 38:111-116.

Hoyt, D.R., et al.

1980 "Life satisfaction and activity theory: a multidimensional approach." Journal of Gerontology 35:935-941 
Kreps, J.M.

1980 "Intergenerational transfers and the bureaucracy." Pp. 440-454 in Jill S. Quadagno, (ed.), Aging, the Individual and Society. New York: St. Martin's.

Kuypers, J.A. and V.L. Bengston

1973 "Social breakdown and competence: a model of normal aging." Human Development 16:181-201.

Larson, R.

1978 "Thirty years of research on the subjective well-being of older Americans." Journal of Gerontology 33:109-125.

Lemon, B.W, V.L. Bengston, and J.A. Peterson

1976 "An exploration of the activity theory of aging: activity types and life satisfaction among in-movers to a retirement community." Pp. 61-86 in Cary S. Kart and Barbara B. Manard, (eds.) Aging in America. Port Washington, NY: Alfred.

Longino, Jr., C.F., K.A. McClclland, and W.A. Peterson

1980 "The aged subculture hypothesis: social integration, gerontophilia and self-conception." Journal of Gerontology 35:758-767.

Mannheim, K.

1952 "The problem of generations." Pp. 276-322 in Karl Mannheim, Essays on the Sociology of Knowledge, Paul Kecskemeti (ed.). New York: Oxford University Press.

Marshall, V.W.

1975 "Socialization for impending death in a retirement village." American Journal of Sociology $80(1): 1124-1144$.

1981 "No exit: a symbolic interactionist perspective on aging." Pp. 79-94 in Cary S. Kart and Barbara B. Manard (eds.), Aging in America. 2nd ed. Sherman Oaks, CA: Alfred.

McQuaide, M. and W.J. Sauer

1979 "The concept of 'cohort': its utility for social gerontology." Sociological Symposium 26 (Spring):28-41.

Mills, C.W.

1959 The Sociological Imagination. New York: Oxford University Press.

Neugarten, B.L.

1974 "Age groups in American society and the rise of the young-old." The Annals of the American Academy of Political and Social Science 415: 187-198.

Neugarten, B.L., R.J. Havighurst, and S.S. Tobin

1976 "The measurement of life satisfaction." Pp. 124-147 in Cary S. Kart and Barbara B. Manard (eds.), Aging in America. Port Washington, NY: Alfred.

Neugarten, B.L., J.W. Moore, and J.C. Lowe

1980 "Age norms, age constraints, and adult socialization." Pp.161-171 in Jill S. Quadagno, (ed.), Aging, the Individual and Society. New York: St. Martin's.

O'Connor, J.

1973 The Fiscal Crisis of the State. New York: St. Martin's.
Olson, L.K.

1982 The Political Economy of Aging: The State, Private Power, and Social Welfare. New York: Columbia University Press.

Orbach, H.L.

1974 "The disengagement controversy." Chapter III of The Disengagement Theory of Aging, 1960-1970: A Case Study of Scientific Controversy. Unpublished Ph.D. dissertation. University of Minnesota.

Reichard, S., F. Livson, and P.G. Peterson

1962 Aging and Personality, New York: Wiley.

Reimer, Y., and R.H. Binstock

1980 "Campaigning for 'the senior vote': a case study of Carter's 1976 cam paign." Pp. 394-406 in Jill S. Quadagno (ed.), Aging, the Individual and Society. New York: St. Martin's.

Riley, M.W.

1971 "Social gerontology and the age stratification of society." The Gerontologist $11(1): 79-87$.

1980 "Age and aging: from theory generation to theory testing." Pp. 339 348 in Hubert M. Blalock, Jr., (ed.), Sociological Theory and Research: A Critical Appraisal. New York: Free Press.

Rose, A.M.

1965 "The subsulture of the aging: a framework for research in social gerontology." Pp. 3-16 in Arnold M. Rose and Warren A. Peterson, (eds.), Older People and Their Social World. Philadelphia: F.A. Davis.

Sheppard, A.

1981 "Response to cartoons and attitudes toward aging." Journal of Gerontology $36: 122-126$.

Simmons, L.W.

1960 "Aging in preindustrial societies." Pp. 62-91 in Clark Tibbits, (ed.) Strieb, G. Handbook of Social Gerontology. Chicago: University of Chicago Press.

1965 "Are the aged a minority group?" Pp. 311-328 in Alvin W. Gouldne and S.M. Miller, (eds.); Applied Sociology: Opportunities and Problems. New York: Free Press.

Walker, A.

1981 "Towards a political economy of old age." Ageing and Society 1(1): 73-94.

Walker, G.K.

1984 "The Reagan administration and Medicare: making hospitals and beneficiaries subject to market forces." Paper presented to the Midwest Council for Social Research on Aging, seminar held Kansas City, Missouri, February, 1984

Weber, $\mathrm{M}$.

1904 “'Objectivity' in social science and social policy." Pp. 48-112 in Ed ward A. Shils and Henry A. Finch (trans.), Methodology of the Social Sciences. New York: Free Press. 1949.

1946 "The social psychology of the world religions." Pp. 267-301 in H.H. Gerth and C. Wright Mills, (trans. and eds.), From Max Weber. New York: Oxford University Press. 
Mid-American Review of Sociology

1978 Economy and Society: An Outline of Interpretive Sociology. Guenther Roth and Claus Wittich, (eds.). Berkeley, CA: University of California Press.

Wright, E.O.

1979 Class, Crisis and the State. London: Verso.

\section{NOTES AND COMMENTS}

\section{THE SOCIOLOGY OF MORAL JUDGMENT: SOCIAL AND ETHNIC FACTORS*}

\author{
Anthony J. Cortese \\ Colorado State University
}

\begin{abstract}
Social and ethnic differences in moral judgment are examined and a critique of the cognitive-developmental model is presented in this article. In opposition to Piaget and Kohlberg, the thesis advanced here is that morality and moral development are culturally and socially determined constructs. While Piaget postulated the presence of qualitatively distinct stages of moral development to be found in all societies, the position presented here is that the number of stages, the content of the stages, and the order of the stages varies across cultures. While Kohlberg asserts that morality is located in the psychological structures of the individual, our position is that moral reasoning and behavior is largely determined by such social factors as role demands, class interests, national policies and ethnic antagonisms. Moreover, one cannot be moral in an immoral social role irrespective of childhood socialization, psychological predispositions or commitment to abstract principles.
\end{abstract}

Piaget (1952) viewed cognitive development as consisting of a sequence of stages, proposing the stages to be universal and invariant. Social transmission (e.g., culture, family) was considered a key variable in the rate of development according to Piaget's early writings. Piaget contended that an individual's intellectual development was largely the consequence of social factors, such as language (Piaget, 1926) and parental and peer support and constraint (Piaget, 1965). But while the content of development was socially determined, the structure was not.

Piaget's emphasis on structure is evident in his study of mo ral development (1965). He focused on the application and the consciousness of game rules in order to generate moral stages from behavior patterns he observed in children. Piaget's method was to play marbles

${ }^{*}$ The author gratefully acknowledges T.R. Young for his helpful comments on this paper. 